日酰外会誌 $49(1), 47-54,1988$

症例

特発性血小板減少性紫斑病とバセドウ病とが合併した 1 例

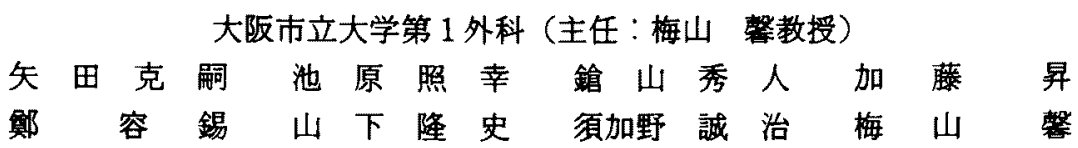

特発性血小板减少性紫斑病（以下ITPと略す）とバセドウ病が合併した，いわゆる overlap 症候群の 1 例を経験し若干の文献的考察を加え報告した。

症例は26歳の女性で焦燥感，手指振戦を主訴として近医を受診し，バセドゥ病の診断 で, 手術目的にて当科に入院となった，入院時血液模查で, 血小板数の著明な减少をみ たはか, 出血時間の延長を認め, 精查の結果 ITP と診断した，そこで甲状腺垔全摘術に ついで脾摘街を行い，経過良好にて退院した。

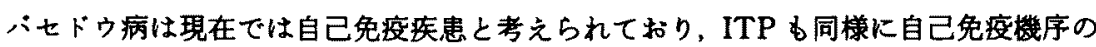
関与があると言われ，ITPにバセドウ病が合併する頻度は諸家により10\%前後と報告さ れている，その治療に関しては，まずバセドウ病の治療を行い，なお血小板数の改善の みられない症例ではステロイド療法、ついで脾摘術等の治療を行うのが現在のところ, 適切な方法たと思われる。

卖引用語：ITP, バセドウ病，overlap 症候群

\section{はじめに}

特発性血小板减少柴病 (以下ITP と略す) と六た ドゥ病が合併した，いわゆる overlap 症候群の1例を 経験したので，若干の文献的考察を加光報告する。

症例

患者：26歳，女性.

主訴：焦燥感，手指振戦。

現病歴：昭和58年夏頃より発汗が著明となった。 た同時期上り焦燥感，動悸，口渴，食欲光進，手指振 戦に気付いた。 また家人より眼球の突出を指摘され某 医を受診し，バセドウ病と診断された。抗甲状腺剂投 与により一時軽块したが，内服中断により再然し，昭 和60年11月 8 日手術目的にて当科を受診した。

また幼少時より鼻出血，技雪後止血困難，皮下出血 ができやすいという既往があった。

入院時現症：眼球突出が認められたか，貧血，黄庭 は認められなかった。

前頻部にびまん性に腫大した著明な strumaを認 め, struma は弾性軟, 表面平滑, 辺縁不明瞭であった。 顠部リンパ節は触知しなかった。胸部では，理学的に 異常所見はなかったが，心尖部にて収縮期雑音が聴取

昭和62年 4 月 30 日受付 62 年 9 月 22 日採用
された，腹部では左季肋部に脾を 3 横指触知する以外 肝は触知せず腹水る見られなかった。主た手指に軽度 の振戦が認められた。

入院時血液検査：Table 1 亿示すごとく血小板数 $1.1 \times 10^{4} / \mathrm{mm}^{3}$ と著明な血小板数減少をみたはか, 出血 時間の延長を認めた。 赤血球数 $468 \times 10^{4} / \mathrm{mm}^{3}, \mathrm{Hb} 9.1$ $\mathrm{g} / \mathrm{dl}, \mathrm{Ht} 26.6 \%$, Fe $20.0 \mu \mathrm{g} / \mathrm{dl}, \mathrm{FeBc} 392.0 \mu \mathrm{g} / \mathrm{dl}$ と鉄欠乏性䏝血を示した。一方甲状腺ホルモンは $\mathrm{T}_{3}$ $1.67 \mathrm{ng} / \mathrm{dl}, \mathrm{T}_{4} 11.9 \mu \mathrm{g} / \mathrm{dl}, \mathrm{TSH} 1.6 \mu \mathrm{U} / \mathrm{ml}$ と軽度機 能穴進を示した. 免疫系では Microsome 25,600, 抗核 抗体20倍で speckled typeを示したが，抗血小板抗体 は陰性であった。

䫫部超音波検査：甲状腺は中等度に肥大し，内部工 コーは hyper $て ゙$ homogenous fine granular pattern を呈していた（Fig. 1).

腹部超音波検查：脾蔵が $129 \times 81 \mathrm{~mm}$ 之著明に腫大 している以外，特記すべき所見は認められなかった。

心灌超音波検査：僧帽弁閉鎖不全が指摘された。

${ }^{51} \mathrm{Cr}$ ラベル血小板による脾肝集樌比：脾と肝の集 穞比を比べると，脾にラベルした血小板が肝に比へ77.9 倍多く取り込まれた。なお正常は 2 倍以下である(Fig. 2).

腹部 CT 娭查：肝ははぼ正常で庫大も萎縮もみられ 
Table 1 入院時険查

\begin{tabular}{|c|c|c|c|c|c|}
\hline RBC & $468 \times 10^{4} / \mathrm{mm}^{3}$ & T.Bil & $0.3 \mathrm{ng} / \mathrm{d} \ell$ & LE & \\
\hline $\mathrm{Hb}$ & $9.1 \mathrm{~g} / \mathrm{dl}$ & TTT & $1.7 \mathrm{U}$ & \multicolumn{2}{|c|}{ Immunoglobulin levels } \\
\hline $\mathrm{Ht}$ & $26.6 \%$ & ZTT & $18.3 \mathrm{U}$ & \multicolumn{2}{|c|}{$\operatorname{lgG} \quad 2904 \mathrm{mg} / \mathrm{d} \ell$} \\
\hline MCV & $57 \mu^{3}$ & GOT & $18 U$ & \multicolumn{2}{|c|}{$357 \mathrm{mg} / \mathrm{d} \ell$} \\
\hline $\mathrm{MCH}$ & $19.4 \gamma \gamma$ & GPT & $15 U$ & \multicolumn{2}{|c|}{$255 \mathrm{mg} / \mathrm{dl}$} \\
\hline $\mathrm{MCHC}$ & $34.1 \%$ & LDH & $288 W U$ & \multicolumn{2}{|c|}{$<500 \mathrm{U} / \mathrm{m}$} \\
\hline WBC & $9.200 / \mathrm{mm}^{3}$ & ALP & $11.7 \mathrm{KAU}$ & \multicolumn{2}{|c|}{ 測定不能 } \\
\hline Plate let & $1.1 \times 10^{4} / \mathrm{mm}^{3}$ & $\gamma$ GTP & $4 \mathrm{mu} / \mathrm{ml}$ & \multicolumn{2}{|c|}{$\mathrm{C}_{3}(100 \pm 30) 50 \mathrm{mg} / \mathrm{d} \ell$} \\
\hline Bleeding $\mathrm{T}$. & $>15 \mathrm{~min}$ & ChE & $0.87 \triangle P H$ & \multicolumn{2}{|c|}{$C_{4}(20 \sim 50) \quad 15 \mathrm{mg} / \mathrm{d} l$} \\
\hline Clotting $\mathrm{T}$. & $7.30 \mathrm{~min}$ & T.chol & $9.8 \mathrm{mg} / \mathrm{d} \ell$ & \multicolumn{2}{|c|}{ Anti DNA Ab $6.2 U / m \ell$} \\
\hline PT & $10.4 \mathrm{sec}$ & ICG(15) & $3.7 \%$ & \multicolumn{2}{|c|}{ Microsome test 25600} \\
\hline HPT & $122 \%$ & Serum Fe & $20.0 \mu \mathrm{g} / \mathrm{d} \ell$ & Thyroid test & 100 \\
\hline $\operatorname{ESR}\left(1^{\circ}\right)$ & $10 \mathrm{~mm}$ & $\mathrm{FeBc}$ & $392.0 \mu \mathrm{g} / \mathrm{dl}$ & 抗校抗体 & 20倍 \\
\hline$\left(2^{\circ}\right)$ & $28 \mathrm{~mm}$ & BUN & $12 \mathrm{mg} / \mathrm{dl}$ & \multicolumn{2}{|c|}{ (Speckled type) } \\
\hline T. pro. & $6.9 \mathrm{~g} / \mathrm{d} \ell$ & Creatinine & $0.6 \mathrm{mg} / \mathrm{dl}$ & \multicolumn{2}{|c|}{ 抗ENA抗体 <100倍 } \\
\hline alb & $3.8 \mathrm{~g} / \mathrm{d} \ell$ & RA & $\Theta$ & \multicolumn{2}{|c|}{ 免疫䙉合体 $4.9 \mathrm{mcg} / \mathrm{m} \ell$} \\
\hline$a,-g \ell$ & $3.0 \%$ & HBs Ag & $\Theta$ & \multicolumn{2}{|l|}{ PHA-BT 714} \\
\hline$a_{2}-g \ell$ & $6.0 \%$ & HBs Ab & $\Theta$ & \multirow{2}{*}{\multicolumn{2}{|c|}{ CON-A-BT $227 \mathrm{SI}$}} \\
\hline is-ge & $9.5 \%$ & Coombs & $\rightarrow$ & & \\
\hline$\gamma-g \ell$ & $22.6 \%$ & & & & \\
\hline
\end{tabular}

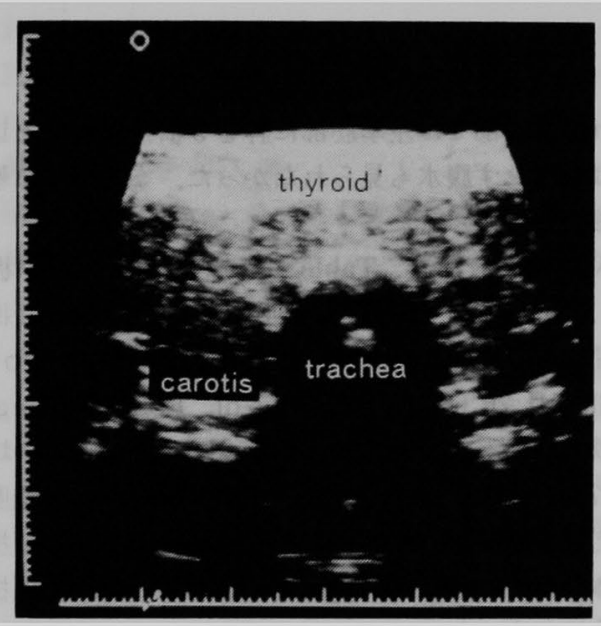

Fig. 1 䫫部超音波検査

ず, 内部所見も homogenous で肝硬変を思わせる所見 は認めなかった．また脾は著明に腫大していた（Fig. 3).

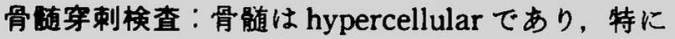
Megakaryocyte の增加が見られた。

\section{経 過}

Table 2 に甲状腺機能の経過を示す，入院時軽度甲 状腺機能六進を示したか，抗甲状腺剤投与により， euthyroid となった。しかし血小板减少の原因が抗甲

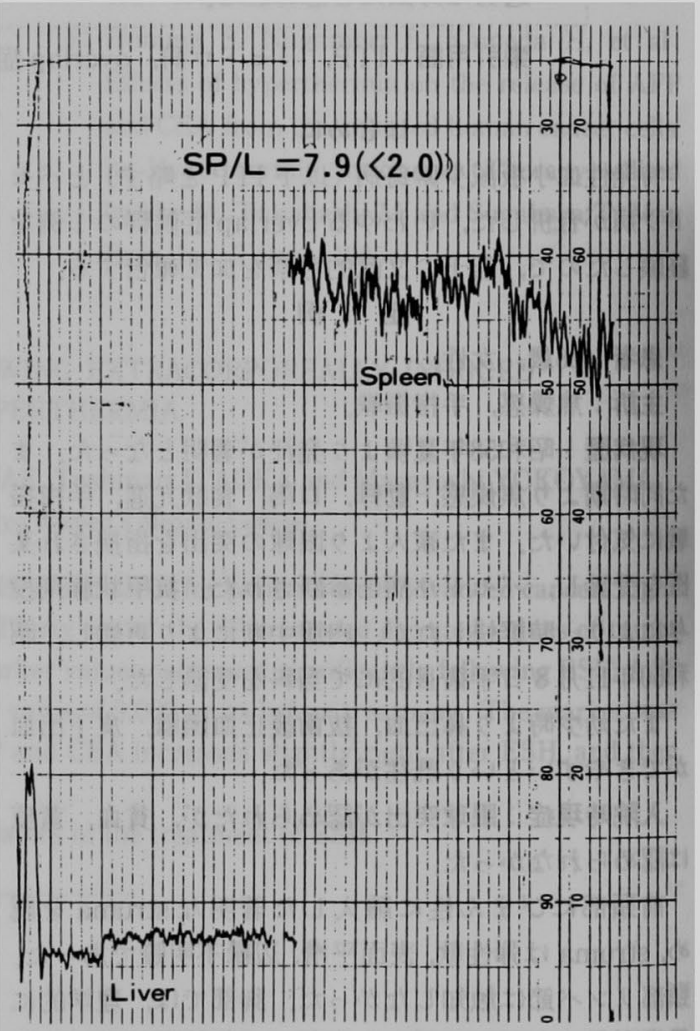

Fig. $2{ }^{51} \mathrm{Cr}$ ラベル血小板による脾肝集程比 
Table 2 甲状腺機能の推移

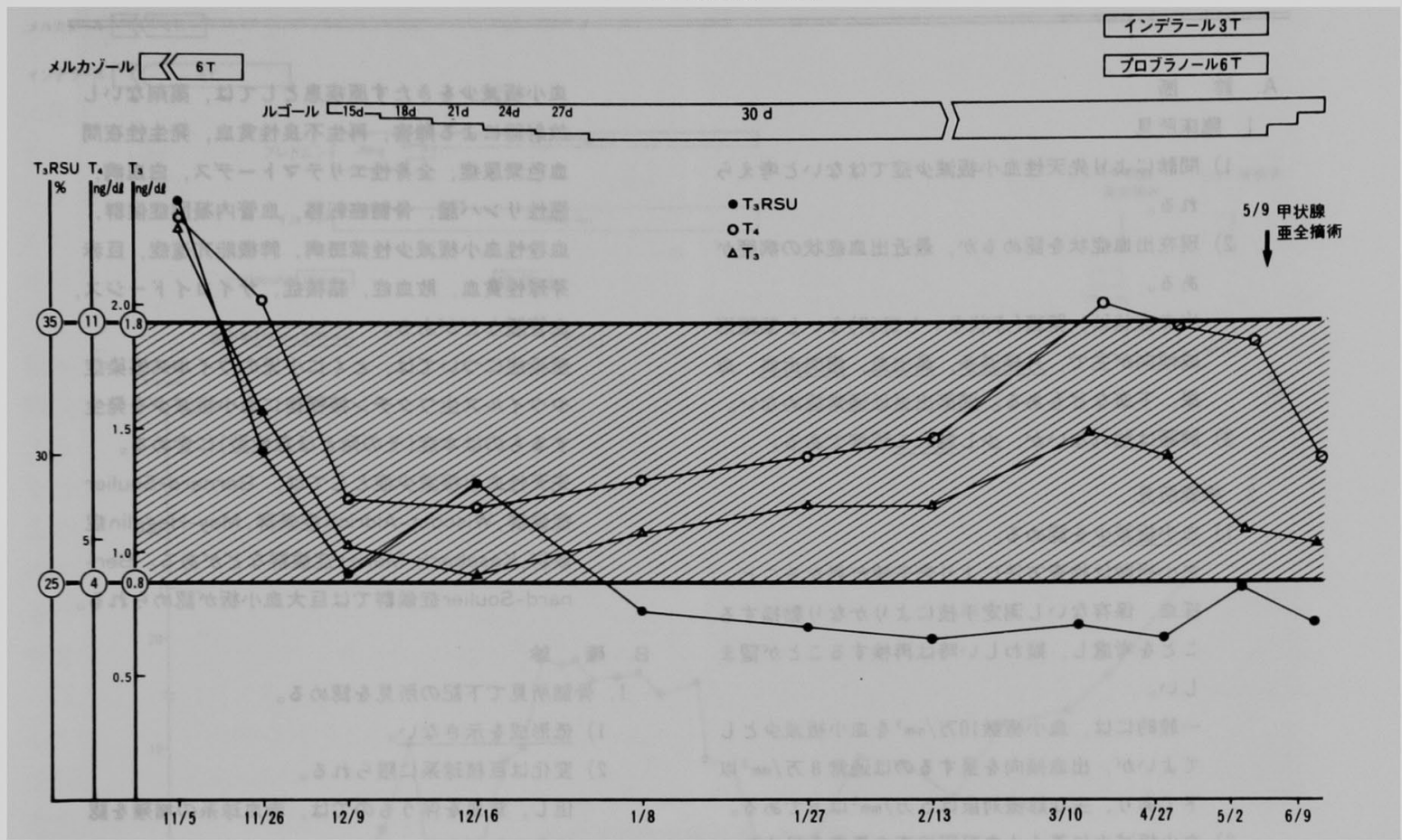

斜線は正常域を示す。

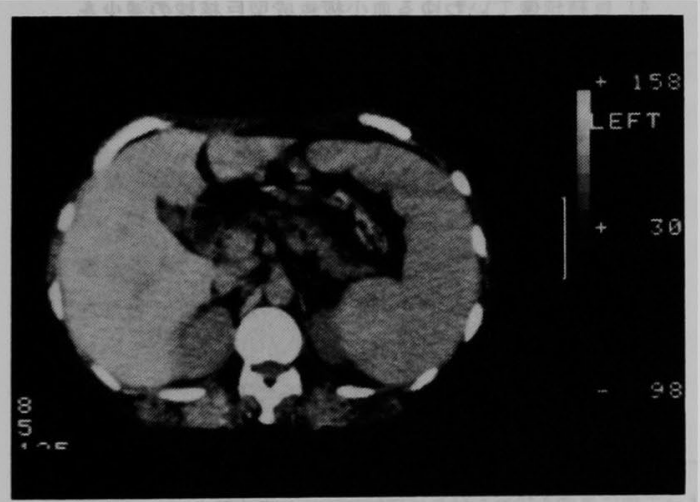

Fig. 3 腹部 CT 検査

状腺剤による可能性す考え, メルカソール,インデラー ルを相次いで中止した。

また血小板数 $1.1 \times 10^{4} / \mathrm{mm}^{3}$, 赤血球数 $468 \times 10^{4} /$ $\mathrm{mm}^{3}, \mathrm{Hb} 9.1 \mathrm{~g} / \mathrm{dl}, \mathrm{Ht}$ 值 $26.6 \%$ と著しい血小板减少と 鉄欠乏性貧血を認めたため，その検索をすすめた結果， Table 3 に示すITP の診断基準より, ITP と判断し た.

Table 4 に血小板数の推移を示す. 12月 7 日より $\gamma \cdot$ globulin 大量投与を始めた。投与後 2 日目より血小 板数は上昇を始め，投与 14 日目に血小板数 $11.5 \times 10^{4} /$ $\mathrm{mm}^{3}$ とピークに達したが, その後急激に減少し, プレ ドニン，イムランによる維持療法にも反応せず，19日 目には血小板数 $1.8 \times 10^{4} / \mathrm{mm}^{3}$ と投与前値にまで減少 した。そこで内科的治療に抵抗すること， ${ }^{51} \mathrm{Cr}$ ラベル 血小板による脾肝集積比が7.9倍と高いこと, 集積比の 高いITP 患者に対して脾摘の成績の良いこと 摘術の適応と判断し，血小板上昇後手術を目的として 昭和61年 1 月 7 日より再び $\boldsymbol{\gamma}$-globulin 大量㞠法を開 始した。 しかし投与開始直後より GOT, GPT が上昇 し始め, GOT 185KU, GPT $387 \mathrm{KU}$ と肝機能障害高 度となったため手術を延期し，肝庇護剤を投与した。

5 月になって肝機能がようやく安定した。 また血小 板数す10万台と安定しているため，5月9日甲状腺亜 全摘術，5月27日脾摘術を行った。

手術所見では, 甲状腺は diffuse に腫大し, 赤色調, 血流豊富な典型的なバセドウ病の甲状腺の所見を呈し ていた. 切除量は右 $20.5 \mathrm{~g}$, 左 $21.5 \mathrm{~g}$, 計 $42 \mathrm{~g}$, 推定残置 量は右 $3.5 \mathrm{~g}$, 左 $4.5 \mathrm{~g}$, 計 $8 \mathrm{~g}$ で切除率は $84 \%$ であった (Fig. 4). 


\section{A. 制}

1. 略床所見

1）閏により先天性血小板娍少柾ではないと费えら n了。

2）現在出血症状を㑇めるか，叟近出血症状の病歴が ある。

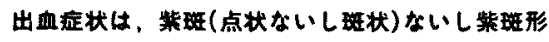

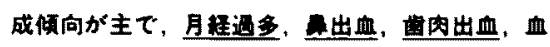

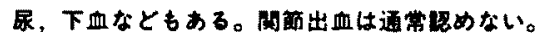

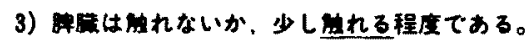

\section{2. 湌企所見}

1）血小板浅少を㑇める。 血小板数は检㚗方法により若干僬が算なること、 探血，保存ないし测定手技によりかなり期播する

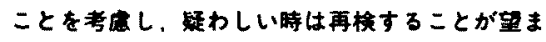
しい。

一般的には，血小板数 10 万 $/ \mathrm{mm}^{3}$ を血小板娍少とし てよいが，出血倾向を呈するのは通常 8 万 $/ \mathrm{mm}^{3}$ 以 下であり，主な部対象は 5 万/ $/ \mathrm{mm}^{3}$ 以下である。

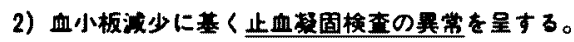

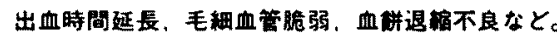

3）通常会血を镜めない。

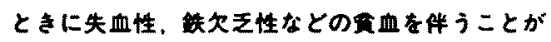

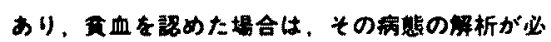
要となる。

4）通裳白血球数は正常ないしやゃ增加してちり，旦

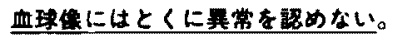

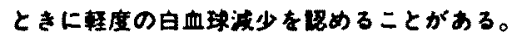

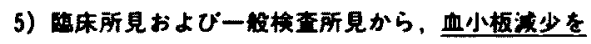

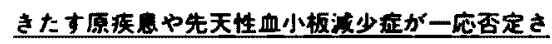
nz.
血小板娍少をきたす原疾忠としては，免刷ないし

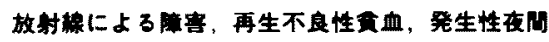
血电来尿症，全身性エリテマトーデス，白血屚，

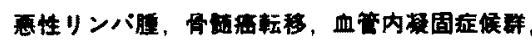

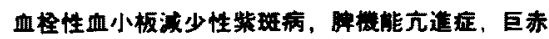

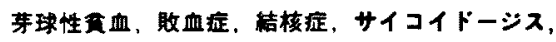
血管胵なとがある。

感染症について心，とくに小焻のウイルス染染症 やウイルス生ワクチン接種後に血小板娍少を発生 するものは本症(十の㱠とは急性型)に含める。 先天性血小板娍少症としては, Bernard-Soulier 症侯群、Wiscott-Aldrich 症侯群，May-Hegglin证 侯群，Kasabach-Meritt症候群などがある。Ber-

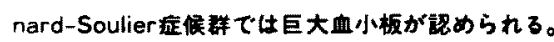

B. 硿

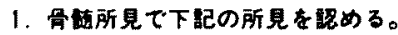

1）焦形成を示さない。

2）密化は巨核球系に限られる。

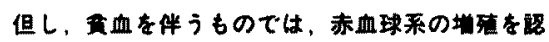
かることがある。

3）巨核球数は正害ないし培加している。

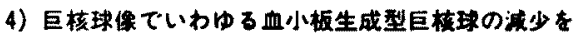
㥸める。

2. 血小板抗体が得性である（とくに輸血歴，好䋗厢の ないちの)。

但し、隆性の域合本症を含定することにはならない。

3. 血小板每命が短綰する。

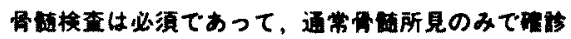
して差支えない。但し，末梢血液の湿入が能かれた 揭合は再模を要する。

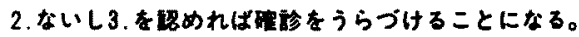

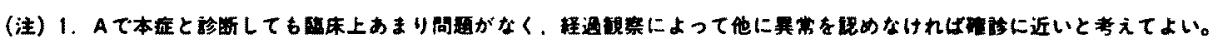

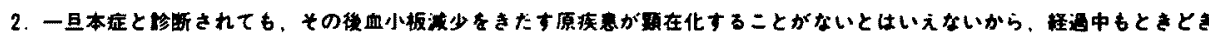

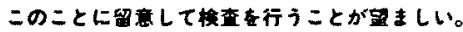

その組織像は,大小のコロイトを含を罣胞が見られ， 㥁胞上皮はやや扁平状一㒶で, 間質のリンパ球浸潤は ごく一部であり典型的なバセドウ病の組織像であった (Fig. 5).

脾脸は中等度に腫大しており，ほぼ三角形で，周曲 との䉥着もなく側副血行は全く発達していなかった。 重量は260gで,大きさは $150 \times 90 \mathrm{~mm}$ で, 脾下極付近大
網内に直径 $8 \mathrm{~mm}$ の副脾を認め,これも摘出した。

Fig. 6 はその免疫組織染色で, 左上 Leu 4は T-cell, 右上 Leu 3a は Helper/Inducer T-cell, 左下 Leu 2a は Suppressor/Cytotoxic T-cell を右下 B1は B-cell を示している.T-cell 域すなわら動脈周用りンパ球䩗， およびB-cell 域りンバ濾胞は共に発達しており，免疫 六進の状態であるが，T-cell subset に関しては，その 
Table 4 血小板の推移

×ルカンールロ

インテラールロ
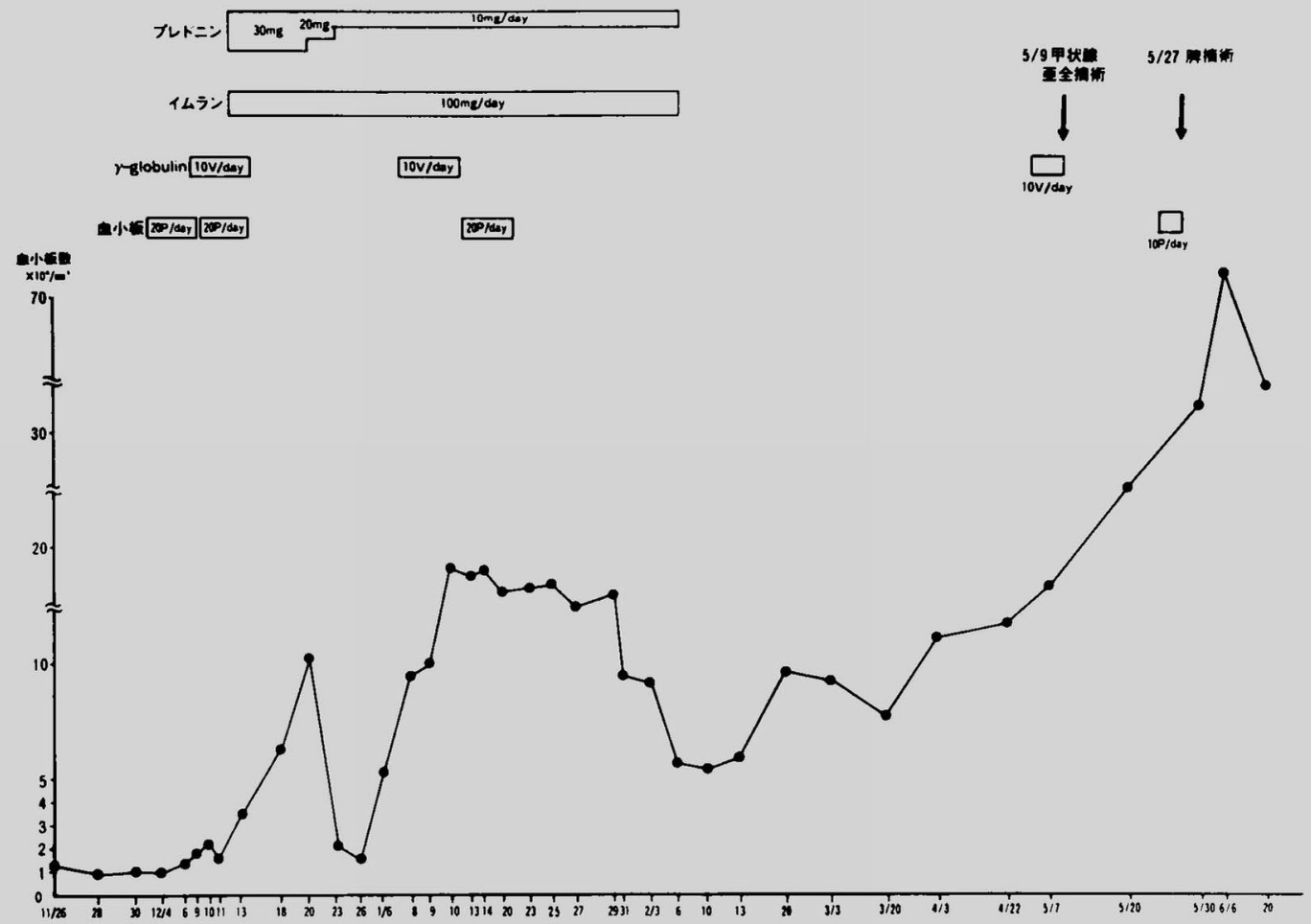

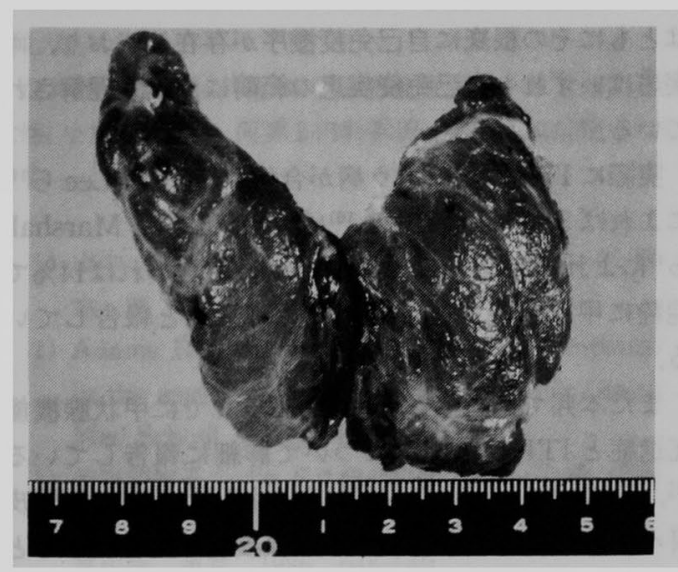

Fig. 4 甲状腺切除椂本

分布に異常を認めなかった. 術後 Table 2,4のごとく 䋊過良好にて，術後 1 力月目に退院した。

考察

ハセドウ病は甲状腺㞌, 眼球突出, 発汗, 心悸穴進,

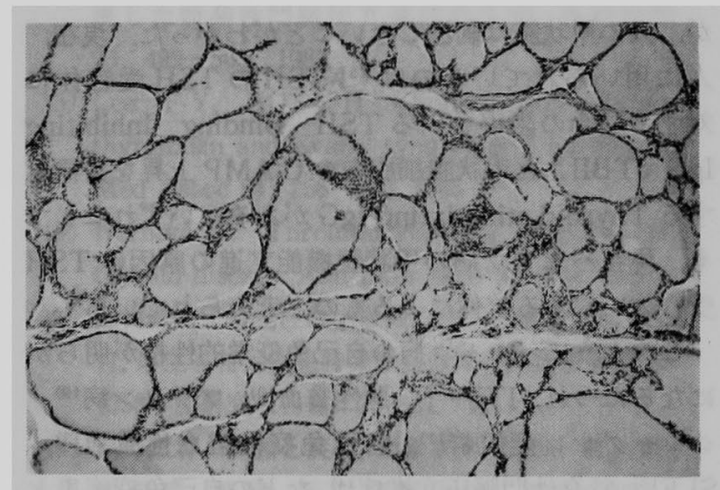

Fig. 5 甲状腺組織像

手指振戦, 焦燥感等種々の病態を示す疾患であり，甲 状腺刺激物質の存在が早くから知られており, ITP 同 様自己免疫機序の関与が考えられる.

バセドウ病の成因については, 1956年 Adams らに より Long Acting Thyroid Stimulator (LATS) か; 

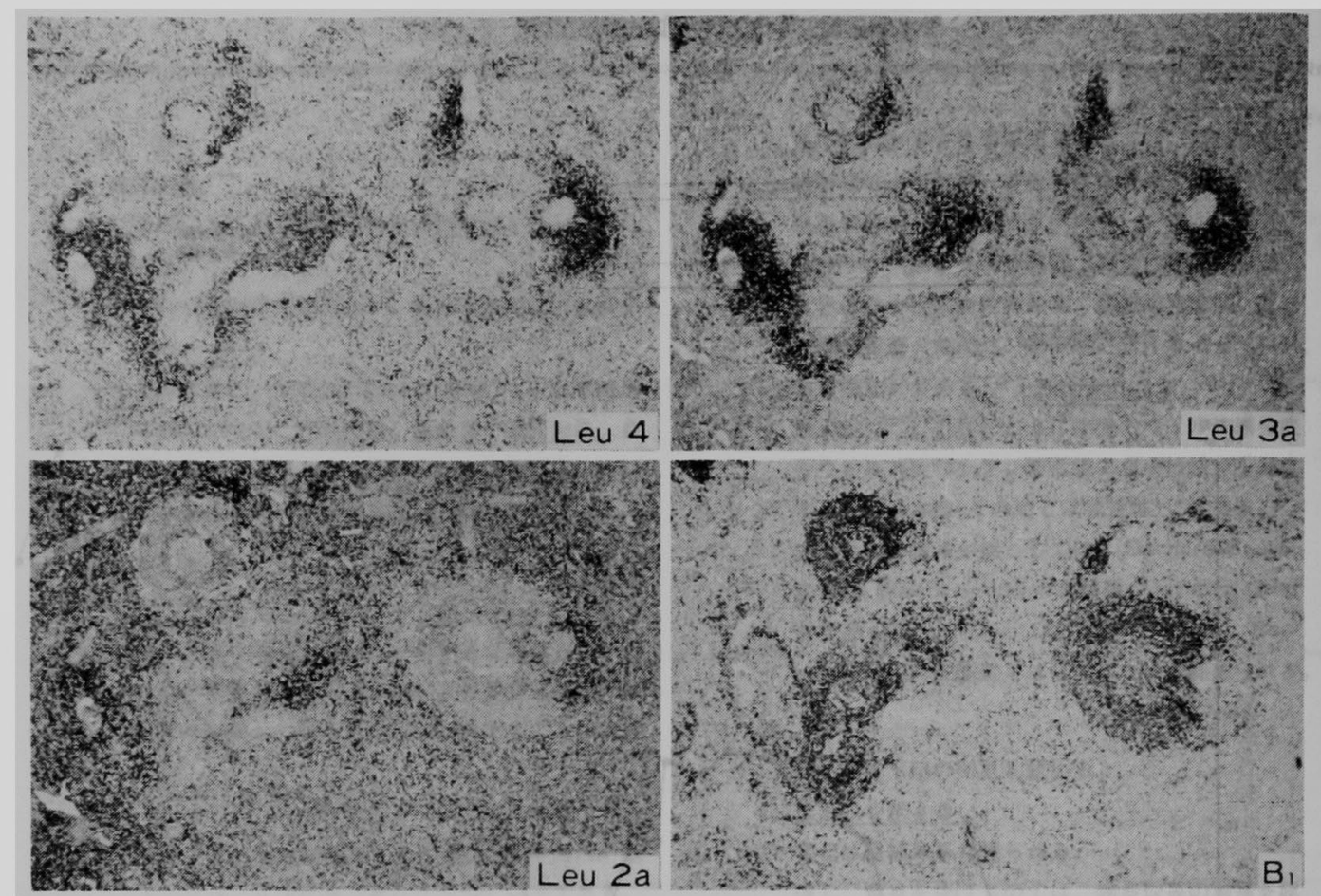

Fig. 6 甲状腺免疫組樴染色

発見されその後LATSは $\boldsymbol{\gamma}$-globulin fractionに あって，甲状腺組織に対する抗体であることが明らか にされた。しかし LATSはマウスの甲状腺は刺激する か，人の甲状腺は刺敫しないことがわかった。現在， 人に用いられているのは125I-TSH の TSH 受容体に 対する結合の阻害をみる TSH Binding Inhibiting IgG（TBII）と甲状腺細胞内の C-AMP 上昇を指標と する Thyroid stimulating IgGがある. いずれにして も, 現在バセドゥ病の甲状腺機能六進の原因は TSH 受容体に対する抗体によるるのと考えられている3 .

このようにバセドゥ病の自己免疫学的性格が明らか になるにつれ, ITP() 9), 覀性筫血 ${ }^{10)}$, フシンン病 ${ }^{10)}$, シェーグレン症候群 ${ }^{11)}$, 自己兔疫性溶血性負 血 $^{12}$, $\mathrm{SLE}^{13)}$, 特発性門脈圧穴進症 ${ }^{14)}$, などの自己免疫疾患と バセドウ病とが合併する overlap 症候群の報告が見ら れるようになった。

一方 ITPはその成因について不明の点が多いが，抗 血小板抗体の存在により血小板減少が起こるとされて いる. Lee ら ${ }^{15}$ によれば, ITP患者の5ち65\%は抗血 小板抗体により血小板が减少するが，残りの35\%は抗 血小板抗体以外の抗体により血小板减少症が起こり,
さらにその成因について, rubella, munpus, mononucleosis, cytomegalo virus, などの感染症もその一因 となると述べている.しかしITP とバセドウ病の成因 はともにその根底に自己免度機序が存在しており, 両 疾患はいずれる自己免疫疾患の範詈にあると理解され ている.

実際にITPにパセドウ病が合併する率は, Lee ら ${ }^{15)}$

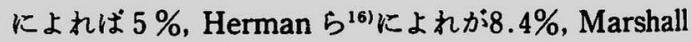
ら゙によれば latent Graves disease す含めれば14\%で 純粋に甲状腺機能六進を示すのは $10 \%$ と報告してい る.

また本邦では吉沢ら5゙が，1982年までに甲状腺機能 亢進症と ITP 合併35例について詳細に報告している が，その中で25例 (71.4\%) に，抗甲状腺剤，副堅皮 質ホルモン等の治療により甲状腺機能が正常化すると 共に，血小板数の回復正常化が認められており，この らち抗甲状腺刘単独治療により血小板数の上昇したも のは 8 例にみられたと報告している.

この事実から, 甲状腺機能元進症が血小板数減少に 影響を与えていることは確かであろう，同様の報告は

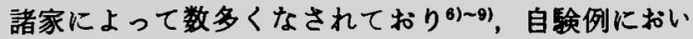


ても甲状腺機能の安定化とともに血小板数の增加が認 められ，これらの説を支持する成績であった。

治療であるか，甲状腺機能六進症の病態生理はITP に悪影留を扰よばすと考えられるので，まず内科的あ るいは外科的に甲状腺譏能元進症に対して治療をする ことが必要であると考える，たとえ甲状腺譏能六進症 が明らかでないITP 症例でも，治療に抵抗するむので は詳細に甲状腺譏能検査を行ら必要があるとされてい る”. 一方 ITPに関しては厚生省特定疾患特発性血小 板減少性紫斑病調査研究斑の「ITP の治㞠に関する多 施設共同プロスベクティブ研究」のプロトコール17゙に よると，副堅皮質ステロイド投与後 6 力月で奻果判定 を行い，脾摘を行らか否かを決定するようになってい るが，本邦では脾摘例はいまだ少ない，欧米ではITP の約半数は脾摘されているょうでその成績も良好であ る(8) 200. 山中ら"む，脾摘はステロイド療法に比へて， 有意に予後が良好であると報告している。

以上より，ITPと甲状腺機能六進症の合併例にたい しては，まず甲状腺譏能六進症の治療を行い，なお血 小板数, 出血佰向の改善しないるのに対しては、ステ ロイト㞠法，ついで脾摘術等の治㞠を行らのが琴在の ところ適切な万法だと思われる。

$$
\text { おわりに }
$$

overlap 症候群として発症したITPと合併したハ セドウ病の 1 例を経験したので，その臨床所見を述へ るとともに，成因について若干の文献的考察を加え報 告した.

なお御指導いただいた本学臨床検査医学，日吉基文，任 太性，小島和英先生，同第 2 内科兵田 算先生に感碀いたし ます。

$$
\text { 文嗝 }
$$

1）山中 学, 野村武夫：ITP の長期予後について, 臨 血 $26: 171-176,1985$

2) Adams DD, Purves HD: Abnormal response in the assay of thyroiteopin. Proc Univ Otago Med School $34: 11-12,1956$

3）前田美智子：バセドゥ病の病因。バセドウ病，伊藤 国彦編，甲状腺垁患〈臨床 VISUAL Mook5〉，金 原出版，東京，1986，p48-49

4) Marshall JS, Weisberger AS, Levy RP: Coexistent idiopathic thrombocytopenic pur. pura and hyperthyroidism. Ann Intern Med 67 : 411-414, 1967

5）吉沢 要、鉿木陽一，今井俊茂他：バセドウ病と特 発性血小板减少性紫班病の合併した 1 例，臨血
$23: 185-192,1982$

6) Kurata $Y$, Tsubakio $T$, Nishioeda $Y$, et al : Seven cases of idiopathic thrombocytopenic purpura associated with Graves'disease, 日血会 誌 $44: 951-956,1981$

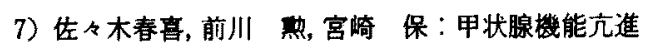
症に合併したITP(特発性血小板减少性紫斑病)の 1 例, 旭川病医誌 $14: 31-35,1981$

8）井上昌光, 山田克典, 松村茂一他：甲状腺機能充進 症に特発性血小板减少性紫病を合併した 2 症 例, 山口医 $32: 217-221,1983$

9）起野 健, 岸田 䇣, 原田実根他：抗甲状腺㓩単独 投与に上り治筧したバセドウ病合併血小板减少性 紫玟病の1例，内科 $54: 979-982 ， 1984$

10) Anderson JR, Kathleen GG, Middleton DG, et al: Autoimmunity and thyrotoxicosis. Brit Bed J $2: 1630-1632,1964$

11）岡厚, 藤本吉秀, 内田久則: 自己兔度性甲状腺 炎を伴っだ゚セドウ病にシェータレン症候群を合 併した 1例，臨外 22：1325-1329，1967

12）太田千籍子, 伊藤宏雄, 内藤 操他：甲状腺機能六 進症に合併した自己免产性溶血性算血の 1 例，日 内会誌 $70: 1190,1981$

13）岡村 绿, 重政千秋, 吉田明雄他：SLE 様症状を とすなっだセド病症例の㭘討, 臨免疫 14 ： $237-242,1982$

14）吉川和彦, 沈 敬輔, 山下隆史他：バセドウ病を合 併した特発性門脈王六進症の 1 例，外科診療 $25: 499-505,1983$

15) Lee F.Y, HO C.H Chong L.L: Hyperthyroidism and Evans' syndrome. J Formosam Med Assoc 84 : 256-260, 1985

16) Herman J: Thrombocytopenic purpura and thyroid disease. Ann Inter Med 93: 934, 1980

17）野村武夫：特発性血小板隇少性紫斑病分科委会報 告. 厚生省特定疾患特発性造血障害調查研究班, 昭 和58年度研究報告書, 26-31，1984

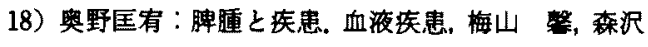
成司编，脾眼，医学图書出版，東京，1983， p183-214

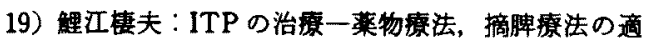
心と限界, クリ二カ $5: 150-153,1978$

20) Schwartz SI, Hoepp LM, Sachs S: Splenectomy for thrombocytopenia. Surgery 88 : 497-506, 1980 


\title{
A CASE OF COEXISTENT IDIOPATHIC THROMBOCYTOPENIC PURPURA (ITP) AND BASEDOW'S DISEASE
}

\author{
Katsushi YADA, Teruyuki IKEHARA, Hideto YARIYAMA, Noboru KATO, Yong-Suk CHUNG, \\ Takashi YAMASHITA, Seiji SUGANO and Kaoru UMEYAMA \\ The First Department of Surgery, Osaka City University Medical School
}

A case of coexistent ITP and Basedow's disease, so-called overlap syndrome, is reported.

A 26-year-old female was admitted to our department with a chief complaint of restlessness and finger tremor.

Laboratory data and clinical findings showed a decreased platelet count, bleedingtendency and hyperthyroidism. After a diagnosis of coexistent ITP and Basedow's disease, subtotal thyroidectomy followed by splenectomy was performed without any complications. Recently, both Basedow's disease and ITP have been thought to be autoimmune diseases.

Some previous papers have reported that about $10 \%$ of patients with ITP have accompanying Basedow's disease. In this situation, hyperthyroidism should initially be treated with antithyroid drugs or by subtotal thyroidectomy. If ITP does not improve following these therapies, steroid therapy is indicated, and splenectomy is also advisable. 